\title{
Correction to: Daunorubicin/Cytarabine Liposome: A Review in Acute Myeloid Leukaemia
}

\author{
Hannah A. Blair ${ }^{1}$
}

Published online: 12 December 2018

C) Springer Nature 2018

\section{Correction to: Drugs \\ https://doi.org/10.1007/s40265-018-1022-3}

The article Daunorubicin/Cytarabine Liposome: A Review in Acute Myeloid Leukaemia, written by Hannah A. Blair, was originally published Online First without open access. After publication online Jazz Pharmaceuticals, Inc., requested that the article be Open Choice to make the article an open access publication. Post-publication open access was funded by Jazz Pharmaceuticals, Inc. The article is forthwith distributed under the terms of the Creative Commons Attribution-NonCommercial 4.0 International License (http://creativecommons.org/licenses/by-nc/4.0/), which permits any noncommercial use, duplication, adaptation, distribution and reproduction in any medium or format, as long as you give appropriate credit to the original author(s) and the source, provide a link to the Creative Commons license and indicate if changes were made.

The original article can be found online at https://doi.org/10.1007/ s40265-018-1022-3.

Hannah A. Blair

demail@springer.com

1 Springer, Private Bag 65901, Mairangi Bay, Auckland 0754, New Zealand
The original article has been corrected.

Open Access This article is distributed under the terms of the Creative Commons Attribution-NonCommercial 4.0 International License (http://creativecommons.org/licenses/by-nc/4.0/), which permits any noncommercial use, distribution, and reproduction in any medium, provided you give appropriate credit to the original author(s) and the source, provide a link to the Creative Commons license, and indicate if changes were made. 